\title{
Tinjauan Terhadap Grup Cogenerated secara Hingga
}

\author{
Edi Kurniadi \\ Program Studi Matematika FMIPA Universitas Padjadjaran \\ Jalan Raya Bandung Sumedang KM 21 Jatinangor 45363 \\ email: edi.kurniadi@unpad.ac.id
}

\begin{abstract}
ABSTRAK
Dualitas antara grup bebas dan grup divisible memotivasi munculnya konsep dual terhadap grup yang dibangun secara hingga. Suatu sistem $L$ dari unsur-unsur grup $A$ dikatakan sistem cogenerator jika untuk setiap grup $B$, setiap homomorfisma $f$ dari $A$ ke $B$ sedemikian sehingga $L \cap \operatorname{Ker} f$ adalah himpunan hampa atau 0 harus suatu monomorfisma. Dalam makalah ini dilakukan suatu tinjauan terhadap sistem hingga $L$ dari cogenerator yang disebut dengan grup cogenerated secara hingga.
\end{abstract}

Kata kunci : dual grup, cogenerator, grup dibangun secara hingga, grup cogenarated secara hingga

\section{ABSTRACT}

The duality between free and divisible groups motivate a concept dual to finitely generated groups. A system L of elements of a group $A$ is called a system cogenerators if for every group B, every homomorphism f from A into B such that $\boldsymbol{L} \cap \operatorname{Ker} \boldsymbol{f}$ equal to empty or 0 must be a monomorphism. In this paper we review a finite system cogenerators that is called cogenerated finitely group.

Keywords: dual group, cogenerators, finitely generated group, and finitely cogenerated group

\section{Pendahuluan}

Konsep dual dapat digunakan untuk mempelajari teori dasar coalgebra dalam Hopf Algebras seperti dalam tulisan Sweedler [5] dan Sorin [6]. Coalgebra muncul sebagai bentuk dual dari algebra. Demikian juga grup siklik yang dikarakterisasi dengan homomorfisma $\varphi: B \rightarrow A$ dengan $a \in \operatorname{Im} \varphi$ epik dapat didualkan sehingga muncul istilah grup cocyclic.

Istilah grup cogenerated hingga ( finitely cogenerated) merupakan konsep dasar dualitas grup yang dibangun secara hingga (finitely generated). Hasil tersebut analog dengan dualitas antara kondisi maksimum dan minimum serta keekivalenan bahwa grup yang dibangun secara hingga berarti jumlah langsung sebanyak hingga grup-grup siklik dan berarti pula subgrup-subgrup yang memenuhi kondisi maksimum.

Termotivasi oleh konsep-konsep di atas, penulis mengkaji konsep yang berkaitan dengan perluasan essential grup hingga, dan jumlah langsung sebanyak hingga grup-grup cocyclic sebagai keekivalenan dengan grup cogenerated hingga ( finitely cogenerated) [3].

\section{Landasan Teori}

\section{Tipe-Tipe Grup}

Pembahasan konteks aljabar topologi sebagaimana telah dikemukan oleh Massey [4] dipaparkan pada subseksi ini. Misalkan $A$ grup dan $S$ himpunan bagian $A$, simbol $\langle S\rangle$ menotasikan subgrup dari $A$ yang dibangun oleh $S$ yaitu irisan semua subgrup dari $A$ yang memuat $S$. Jika $S$ memuat unsurunsur $a_{i}(i \in I)$, tuliskan $\langle S\rangle=\left\langle\ldots, a_{i}, \ldots\right\rangle_{i \in I}$. Grup yang dibangun secara hingga adalah grup yang mempunyai sistem pembangun hingga. Grup $\langle a\rangle$ adalah grup siklik yang dibangun oleh unsur $a G$. 
Dari [1] diperoleh sifat bahwa order suatu grup siklik sama dengan order pembangunnya yaitu $|\langle a\rangle|=|a|$.

Selanjutnya jika setiap order dari semua unsur di $A$ hingga maka $A$ disebut grup torsi, sebaliknya jika setiap unsur di $A$ berorder tak hingga kecuali 0 maka $A$ dikatakan bebas torsi. Teorema berikut berkaitan dengan grup torsi

Teorema 1. Himpunan $T$ dari semua unsur berorder hingga dalam grup A adalah subgrup A. T grup torsi dan grup kuosien $A / T$ bebas torsi.

Grup primary atau $p$-grup didefinisikan sebagai grup yang order semua unsurnya pangkat $p$ prim fixed dan grup yang memuat semua unsur $a$ di $A$ sedemikian sehingga order $a$ kuadrat bebas bilangan bulat disebut socle $S(A)$ dari grup $A$.

Misalkan $n>0$, maka terdapat dua subgrup dari $A$ yaitu

$$
\begin{array}{ll}
\text { a. } & n A=\{n a \mid a \in A\} . \\
\text { b. } & A[n]=\{a \mid a \in A, n a=0\} .
\end{array}
$$

Dapat ditunjukkan bahwa keduanya subgrup dari $A$.

Selanjutnya diberikan $a \in A$, bilangan bulat terbesar nonnegatif $r$ sedemikian sehingga $p^{r} x=a$ dapat diselesaikan untuk suatu $x \in A$ disebut $p$-height a yang dinotasikan dengan $h_{p}(a)$. Jika $p^{r} x=a$ dapat diselesaikan untuk sembarang $r$ maka $a$ disebut $p$-height tak hingga yaitu $h_{p}(a)=\infty$. Untuk $p$ prim tuliskan $h_{p}(a)$ dengan notasi $h(a)$. Untuk $p$-grup diperoleh $S(A)=A[p]$.

Subgrup $E$ dari grup $A$ dikatakan essential jika $E \cap B \neq 0$ untuk setiap subgrup $B$ dari $A$ yang nontrivial. Dalam hal ini, $A$ dikatakan perluasan essential dari $E$

Hasil berikut analog dengan yang dikemukakan penulis dalam hasil dan pembahasan.

Teorema 2. Jika A suatu grup maka kondisi berikut ekivalen

(i) A dibangun secara hingga

(ii) A jumlah langsung sebanyak hingga grup-grup siklik

(iii) Subgrup A memenuhi kondisi maksimum

Unsur a dari suatu grup $A$ dapat dibagi (divisible) oleh bilangan bulat positif $n$, dinotasikan oleh $n \mid a$, jika persamaan

$$
n x=a, \quad(a \in A)
$$

dapat diselesaikan di $A$. Ekivalen dengan mengatakan bahwa $A$ memuat suatu elemen $b$ sehingga $x=b$ suatu solusi dari (1).

Berikut adalah beberapa konsekuensi dari konsep divisibilitas di atas

1. Jika $x=b$ suatu solusi dari (1) maka koset $b+A[n]$ adalah himpunan semua solusi-solusi dari (1).

2. Jika $A$ bebas torsi, maka solusi dari (1) unik.

3. Jika $(n, o(a))=1$, maka (1) selalu dapat diselesaikan.

4. Jika $A$ jumlah langsung $B$ dan $C$ yaitu $A=B \oplus C$, maka $n \mid a=b+c$ berarti $n \mid b$ dan $n \mid c$. 
Dari konsekuensi di atas diperoleh bahwa suatu grup $D$ dikatakan divisible jika $n \mid a$ untuk semua $a \in D$ dan semua bilangan bulat positif $n$. Contoh grup divisible ini adalah grup himpunan semua bilangan rasional $\mathbb{Q}$, grup quasicyclic $\mathbb{Z}\left(p^{\infty}\right)$, dan grup faktor $\mathbb{Q} / \mathbb{Z}$.

\section{Cogenerator Grup Cocyclic}

Suatu grup siklik dapat dikarakterisasi sebagai grup $A$ yang memuat suatu unsur a sedemikian sehingga sembarang homomorfisma $\varphi: B \rightarrow A$ dengan $a \in \operatorname{Im} \varphi$ epik. Dengan mendualkan konsep tersebut, diperoleh grup cocyclic $C$ jika ada suatu unsur $c \in C$ sedemikian sehingga $\varphi: C \rightarrow B$ dan $c \notin$ Ker $\varphi$ mengakibatkan $\varphi$ monik. Dalam hal ini $c$ disebut cogenerator dari $C$. Maka diperoleh bahwa setiap subgrup adalah kernel dari suatu homomorfisma. Oleh karena itu, cogenerator $c$ tentunya termuat dalam subgrup subgrup $C$ yang tak trivial, yaitu subgrup terkecil dari $C$ yang nontrivial. Dengan demikian diperoleh sifat berikut

Sifat 1. Jika suatu grup mempunyai subgrup terkecil yang tak trivial maka grup tersebut adalah cocyclic dan sembarang unsur tak nolnya dalam subgrup terkecil tersebut adalah cogenerator.

Sebagai ilustrasi grup siklik $\langle a\rangle$ dengan order pangkat prim $p^{k}$ adalah grup cocyclic dengan cogeneratornya adalah semua unsur dari $\langle a\rangle$ yang berorder $p$. Misalkan $G=\langle a\rangle$ grup siklik berorder 4, maka diperoleh hubungan bahwa $e<\left\langle a^{2}\right\rangle\left\langle\langle a\rangle\right.$ yang menunjukkan $\left\langle a^{2}\right\rangle$ subgrup terkecil nontrivial dari $\langle a\rangle$. Oleh karena itu, $G=\langle a\rangle$ grup cocyclic dengan cogeneratornya $a^{2}$.

Tipe lain dari grup cocyclic adalah grup quasicyclic $\mathbb{Z}\left(p^{\infty}\right)$ dengan $p$ bilangan prim. Grup ini diperoleh dari akar pangkat kompleks ke $p^{n}$ dari 1.

Berikut adalah hasil yang cukup penting berkaitan dengan grup cocyclic

Teorema 3. Grup $C$ dikatakan cocyclic berarti $C \cong \mathbb{Z}\left(p^{k}\right)$ dengan $k=1,2,3, \ldots$ atau $\infty$.

\section{Metode Penelitian}

Metode penelitian dalam makalah ini berupa kajian terhadap jurnal matematika khususnya dalam bidang aljabar. Pertama selidiki sifat-sifat yang berlaku pada grup yang dibangun secara hingga. Selanjutnya dilakukan pengembangan untuk dual grup yang dibangun secara hingga. Dual yang dimaksud di sini adalah grup cogenerated hingga.

\section{Hasil dan Pembahasan}

Dalam Fuchs [3] suatu sistem $L$ dari unsur-unsur grup $A$ dikatakan sistem cogenerator jika untuk setiap grup $B$, setiap homomorfisma $f$ dari $A$ ke $B$ sedemikian sehingga $L \cap \operatorname{Ker} f$ adalah himpunan hampa atau 0 harus suatu monomorfisma. Kondisi tersebut ekivalen dengan mengatakan bahwa setiap subgrup tak nol dari $A$ memuat unsur tak nol dari $L$. Subgrup yang dibangun oleh $L$, $\langle L\rangle$, merupakan subgrup essential dari $A$. Subgrup essential adalah suatu sistem cogenerators.

Definisi 1 Grup yang cogenerated secara hingga adalah grup yang mempunyai sistem cogenerator hingga.

Pandang grup cocyclic $G=\langle a\rangle$ berorder 8. Perhatikan bahwa $\left\langle a^{4}\right\rangle$ subgrup terkecil dari $G$ 
Sehingga $a^{4}$ cogenerator dari $G$. Selain itu, G adalah perluasan essential dari $\left\langle a^{4}\right\rangle$. Jadi, $\left\langle a^{4}\right\rangle$ sistem cogenerator hingga dari $G$. Oleh karenanya, $G$ grup cogenerated secara hingga.

Secara umum diperoleh rantai subgrup dari grup cocyclic dengan order pangkat prim $p^{k}$ yaitu

$$
0<\left\langle a^{p^{k-1}}\right\rangle<\left\langle a^{p-2}\right\rangle<\ldots<\left\langle a^{p}\right\rangle<\langle a\rangle
$$

Dalam hal ini dapat dipilih sistem cogenerator $L=\left\langle a^{p^{k-1}}\right\rangle$ dan $L$ hingga sehingga grup tersebut adalah grup cocyclic yang cogenerated secara hingga.

Teorema 2 dalam grup yang dibangun secara hingga analog dengan hasil grup cogenerated secara hingga oleh [2] sebagai berikut

Teorema 4. Untuk suatu grup A kondisi beriku ekivalen

(i) A cogenerated secara hingga

(ii) A perluasan essential dari suatu grup hingga

(iii) A jumlah langsung sebanyak hingga grup-grup cocyclic

\section{Bukti :}

Hanya bagian penting dari Teorema 4 yang akan dibuktikan dan yang medukung pembahasan dalam tulisan ini yaitu $(i) \rightarrow($ ii $)$ dan $(i i) \rightarrow(i i i)$.

(i) $\rightarrow$ (ii) Asumsikan (i) berlaku, akan dibuktikan bahwa $A$ perluasan essential dari suatu grup hingga. Karena $A$ grup yang dibangun secara cogenerated maka $A$ mempunyai sistem cogenerators hingga, katakanlah $L$. Tidak satu pun unsur-unsur di $A$ yang berorder hingga, sebaliknya dapat dipilih subgrup yang nontrivial dengan meniadakan cogenerator tak nol di $L$ dalam suatu grup siklik yang dibangun oleh suatu unsur berorder tak hingga. Diperoleh bahwa L suatu sistem yang memuat unsurunsur berorder hingga sedemikian sehingga $\langle L\rangle$ hingga. Jadi, grup A adalah perluasan essential dari grup hingga $\langle L\rangle$. (ii) terbukti.

(ii) $\rightarrow$ (iii). Sekarang asumsikan bahwa (ii) berlaku yaitu $A$ perluasan essential dari grup hingga $B$. Hal ini berarti diperoleh $A$ grup torsi dengan sebanyak hingga $p$-komponen. Tanpa mengurangi keumuman bukti asumsikan bahwa $A$ dan $B$ keduanya $p$-grup. Oleh karenanya, $A[p]=B[p]$ hingga. Untuk suatu $a \in A$ yang besifat tetap, persamaan $p x=a$ mempunyai tak hingga banyak solusi $\operatorname{di} A$. Pernyataan terakhir terjadi karena $A$ grup torsi. Selanjutnya jika $h(a)=\infty$ maka height dari solusisolusi $x_{1}, x_{2}, \ldots, x_{k}$ tidak semua hingga, yaitu jika $y \in A$ memenuhi $p^{n} y=a$, maka $p^{n-1} y$ salahsatu di antara $x_{1}, x_{2}, \ldots, x_{k}$. Dapat disimpulkan bahwa $a \in A[p]$ dengan height tak hingga sedemikian sehingga dapat diperoleh rantai naik untuk mendapatkan subgrup quasicyclic dari $A$. Karena gabungan subgrup-subgrup quasicyclic dari $A$ yaitu $D$ bersifat devisible berakibat $A=D \oplus C$. Selanjutnya karena $C[p]$ hingga maka height maksimal hingga $m$ dari unsur-unsurnya sedemikian sehingga $p^{m+1} C=0$. Jadi, $A$ jumlah langsung grup-grup cocyclic. (iii) terbukti.

\section{Simpulan}

Telah diberikan tinjauan ulang terhadap grup cogenerated hingga yaitu grup yang mempunyai sistem cogenerator hingga. Grup perluasan essential adalah contoh grup cogenerated hingga dan 
subgrup terkecilnya memuat semua cogeneratornya. Lebih lanjut sifat-sifat grup cogerated hingga telah diberikan dalam Teorema 4. Untuk kajian lebih lanjut dapat dikaji apakah grup cogenerated secara hingga mengakibatkan subgrup-subgrupnya memenuhi kondisi minimum.

\section{Daftar Pustaka}

1. Gallian, 2010, Contemporary Abstract Algebra, 7th edition. Matrix Production Inc.

2. Kurosh, A.G, 1932., Zur Zerlegung unendlicher Gruppen, Math. Ann.106, 107-113.

3. Laszlo Fuchs., 1970, Infinite Abelian Groups. Volume 36-I, Pp 252-274., Academic Press New York and London

4. Massey., 1967., Algebraic Topology : An introduction, Springer Verlag, New York.

5. Moss. E. Sweedler, 1969., Hopf Algebras, W.A. Benjamin, Inc, New York, $1-28$.

6. Sorin,D, 2001., Hopf Algebras An Introduction, Marcel Dekker, Inc, New York, 1-55. 